\title{
Larvacidal Efficacy of Methanolic Extract Papaya (Carica papaya) Leaves against the Vector Mosquito Aedes aegypti
}

\author{
${ }^{1}$ Zahtamal, ${ }^{2}$ Atikah F. Muharromah, ${ }^{3}$ Syamsul A. Ardiansyah, ${ }^{4}$ Nabiilatunnisa and ${ }^{5}$ R.C. Hidayat \\ Soesilohadi
}

\begin{abstract}
Dengue fever is the one of danger disease caused by dengue virus which is infected through species of mosquito Aedes aegypti. Chemical insecticides has been concidered to the development of the resistance in the mosquito species as the impact in vector control. This research aims to analyze the potential of papay a (Carica papay a) leaf as larvacides. Phy tochemical screening of metanolic extract Carica papaya leaf indicated, it has secondary metabolites contain such as plavonoids, terpenoids, saponins, and alkaloids which have been known as toxic to the most of insect include larva of Aedes aegypti. The effect of larvae have been investigated in 4 th and 5th for 48 hours with five different concentrations $0,25 \% 0,5 \% 0,75 \%$ and $1 \%$, abate as positive control and aquades negative control. Lethal concentration of larvae have been investigated and determined by probit analyze. The bioassay showed that LC50 methanolic extract of Papaya leaf (Carica papaya) has an effect to Aedes aegy pti LC50 2,5\%..
\end{abstract}

Keywords - Dengue, Papay a, Aedes, Biolarvacide.

\section{INTRODUCTION}

$\mathrm{M}$ osquitoes is one type of insect belonging to the Order Diptera and Family Culicidae [1].Mosquitoes have two scaly wings, a slender body, and six legs. Mosquito has proboscis, both male and female have different function. In male mosquito proboscis has function to feed nectar, meanwhile female mosquito used proboscis to pierce and suck the blood to provide nutrient for egg[2].

Mosquitoes are the vector mechanical cyclic diseases in humans and animals caused by parasites and viruses [3]. The vector is defined as an animal that carries pathogen from an

Zahtamal Faculty of Biology, Universitas Gadjah Mada, Yogyakarta, Indonesia (phone ; e-mail: zahtamal@gmail.com ).

Atikah F. Muharromah2, Faculty of Biology, Universitas Gadjah Mada, Yogyakarta, Indonesia (e-mail: atikahfitria@yahoo.com).

Syamsul A. Ardiansyah3 Faculty of Biology, Universitas Gadjah Mada, Yogyakarta, Indonesia (e-mail: syamsularif2511@gmail.com).

Nabiilatunnisa4, Faculty of Biology, Universitas Gadjah Mada, Yogyakarta, Indonesia (e-mail: nabiilatunnisa@mail.ugm.ac.id).

R.C.Hidayat Soesilohadi5, Associate Profesor in Laboratory of Entomology Faculty of Biologi, Universitas Gadjah Mada, Yogyakarta, Indonesia (e-mail: hidayat@ugm.ac.id). animal or human to animals or other humans [4]. One of the famous mosquito vector is Aedes aegypti. Aedes aegypty species is a vector causing dengue fever. Another hand, Aedes aegypti is also a vector of yellow fever virus, zika virus and chikungunya. Distribution of Aedes aegypti spreads covering all tropical areas of the world [2]. Dengue fever has become an important public health problem as the number of reported cases continue to increase. Dengue fever is spread through the bite of an infected A. aegypti mosquito[13].

Using vector control is one of method to break down the spreading of vector-borne diseases such as yellow fever, dengue fever and zika which are transmitted by Aedes aegypti. For example is use larvacide to eliminate larva stage of mosquito. Larvacide activity was measured by larval mortality [5]. This observation is about natural larvacide or biolarvacide using papaya leaf that more friendly to environment than chemistry larvacide that caused water pollution and make resistant to mosquito [6].

Carica papaya is member of Caricaceae Family. The leaves of papaya have been shown to contain many active components that can increase the total antioxidant power in blood and reduce lipid peroxidation level, such as papain, chymopapain,cystatin, à-tocopherol, ascorbic acid, flavonoids, cyanogenic glucosides, and glucosinolates [7]. Papaya (Carica papaya) leaf contains flavonoid, alkaloid, and papain enzyme that guess as potential biolarvacide [8]. With the papaya leaf compounds, we can do bioactive exploration to eliminate Aedes aegypti mosquitoes that caused many of vector-borne diseases.

\section{MATERIAL AND METHOD}

\section{A. Time and Place of Research}

This research was conducted on September until February 2017. Extraction of Carica papaya was done at Laboratory of Entomology, FALITMA Faculty of Biology and Faculty of Farmacy Universitas Gadjah Mada .

\section{Sample preparation}

Materials used larvae instar 3rd and 4th of Aedes aegypti, methanol $70 \%$ and fish food for larva. In this research also used rotatory evaporator, Erlenmeyer $1000 \mathrm{~mL}$, glass measure 
$1000 \mathrm{~mL}$, and petridish.

Papaya(Carica papaya) leaves obtained fresh from the garden community located in Bantul district, Yogyakarta, Indonesia. Leaves of Carica papaya were washed and dried in room temperature without direct sunlight. After that, dried leaves blended until delicate. 200 grams of blended used for extraction added $1000 \mathrm{ml}$ methanol for $6 \times 24$ hours in Erlenmeyer $1000 \mathrm{ml}$. Every three days, extract solution was filtered use filter paper and filled y $1000 \mathrm{ml}$ methanol. the filtered extract was evaporated using a rotary evaporator at $45 \mathrm{O} \mathrm{C}$ in $60 \mathrm{rpm}$. Condensed extract were stored in a porcelain dish for maceration process. Few extract were taken to be analyzed for the phytochemical content using Thin Layer Chromatography (TLC) [14] [15].

\section{B. Examination}

This research used different solution concentration $0,25 \%$; $0,5 \% ; 0,75 \% ; 1 \%$ Carica papaya leaf extraction, distilled water as negative control and $1 \%$ abate as positive control. Solution pour in plastic glass, and glass consist of 25 larva Aedes aegypti 3rd and 4th instar. Each treatment have 4 repeating [9].Before we got larva 3rd - 4th instar, we hatched and gave nutrition with fish food.

\section{Mortality larvae observation}

Larval death registration was done in 48 hours, then counted and calculated according to Abbott's formula[6][12].

$$
\text { Mortality }(\%)=\frac{X-Y}{X} 100,
$$

where $X=$ percentage survival in the untreated control and $Y=$ percentage survival in the treated sample.

\section{Data Analysis}

Data which were obtained will determine the significance between treatment outcomes with control test conducted One Way ANOVA and Lethal concentration (LC50) was determined using probit analysis by linear regression equation between $\log$ concentration and probit mortality using SPSS 21.0 software.

\section{RESULT AND DISCUSSION}

The results of bioactive compounds Carica papaya leaves can be seen in the picture below

UV $254 \mathrm{~nm} \quad$ UV $365 \mathrm{~nm} \quad$ Visible $\quad$ UV $254 \mathrm{~nm} \quad$ UV 365 nm Visible
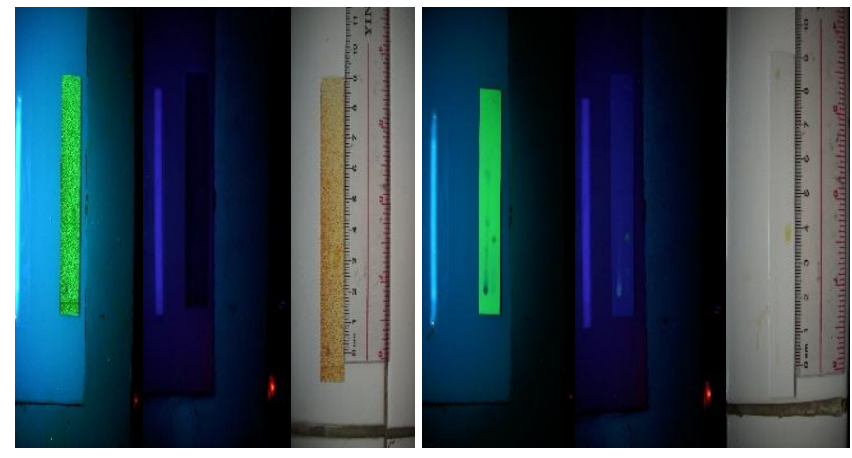

(a) (b)

UV $254 \mathrm{~nm} \quad$ UV $365 \mathrm{~nm} \quad$ Visible UV $254 \mathrm{~nm} \quad$ UV $365 \mathrm{~nm}$ Visible

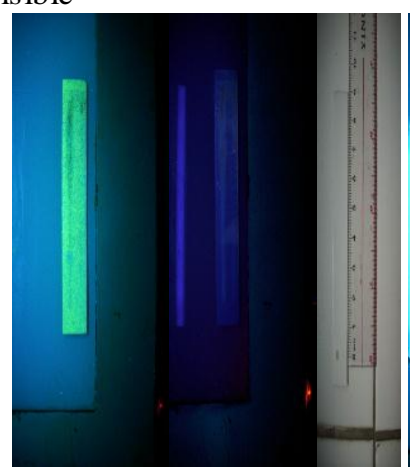

(c)

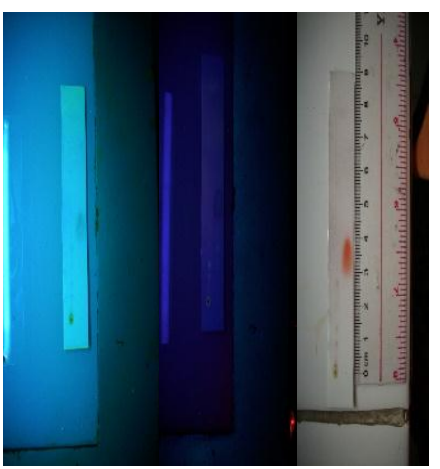

(d)
Fig1. Chromatography test for Secondary metabolites compounds a) Alkaloids b) Flavonoids c) Saponins d) Terpenoid in Methanolic Extract Carica papaya

Larvae mortality during 48 hours showed in the graph below

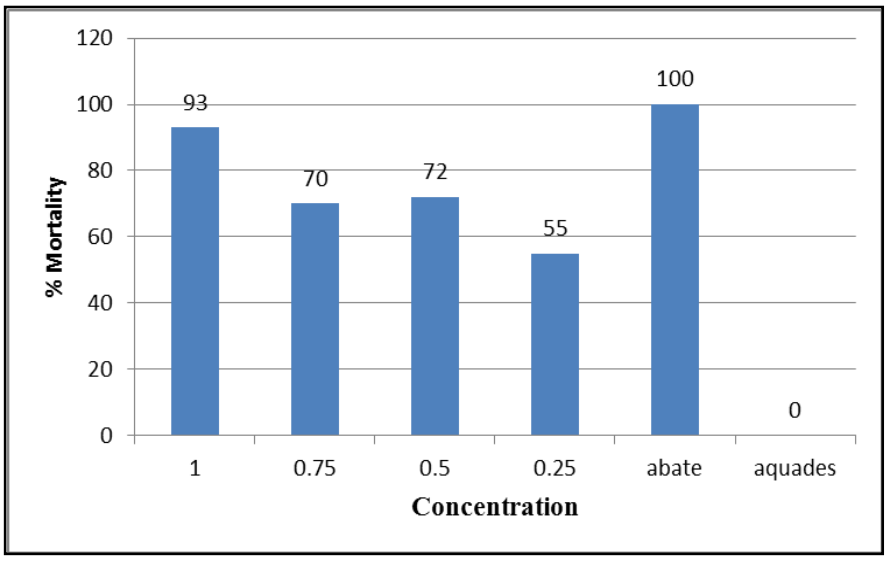

Fig2.Persentage of Aedes aegypti larvae mortality against methanolic extract Carica papay a

Based on Fig. 1, it is known Carica papaya leaf extract has the ability to kill the larvae. it can be seen the concentration of Carica papaya leaf extract with the highest ability to kill the larvae is $1 \%$ as much as $93 \%$ of the larvae and the lowest is $0.25 \%$ concentration as much as $55 \%$ of the larva.

TABLE I.

ANALYSIS OF CARICA PAPAYA LEAF EXTRACT TREATMENT AGAINST 


\section{AEDES AEgYPTI LARVAE}

In this study found the value Lethal concentration (LC50) $0.225 \%$. The result of the regression test showed there results a very strong correlation between the concentration of papaya leaf extract with the death of the larvae of Aedes aegypti.

The purpose of this study was to evaluate the efficacy and effect of the methanol extract leaf papaya to larvae of the Aedes aegypti mosquito. The experiments were conducted to test the content of secondary metabolites in leaves of papaya. Secondary metabolites are bioactive compounds in plants. In general, the content of secondary metabolites in plants has a function as a protection from predators and also microbial. The test results of secondary metabolites done by Thin Layer Chromatography (TLC) the results can be seen in the figure (1). There are four main compounds in papaya leaf and potentially as larvicides there are flavonoids, terpenoids, saponins and alkaloids. Each compound has different role and function as toxic to most of insects.

The effect of larvae have been investigated in the 3rd and 4th instar for 48 hours with five different concentrations of $0.5 \% 0.25 \% 0.75 \%$ and $1 \%$, abate, distilled water as positive control and a negative control. Based on the analysis of significance difference using SPSS 21.0 software, the result shows there is significance of difference between the negative control and treatment, whereas not Significantly difference within positive control. Based on the results obtained the highest mortality is the treatment concentration of $1 \%$ has the percentage of deaths $93 \%$ while the lowest mortality are at a concentration of $0.25 \%$ that had percentage of $55 \%$.

Lethal concentration determined by Probit analyze. The bioassay showed that LC50 methanolic extract of Papaya (Carica papaya) leaf has an effect to an Aedes aegypti LC50 of $0.25 \%$. It's mean that when the larvae are laid out in the interval 48 hours then it will require the concentration of papaya leaves is $0.25 \%$ to kill $50 \%$ larvae[6].

The number of deaths is high on the concentration of $1 \%$ and a low LC50 value could mean that papaya leaf extract is effective as larvicides. Concentration of $0.25 \%$ extract has been able to kill the larvae by $50 \%$. The content of secondary metabolites in papaya is the leading cause death of the larvae Aedes aegypti mosquito. Flavonoids and alkaloids are phenolic which are plant defense compounds that work by inhibiting digestion insects, inhibiting respiration system of insect and toxic for insect [10][11]. Terpenoids are compounds that have a carbon chain. The role of terpenoids against insects by inhibiting insect feeding or reduce the ability of the insect to digest food [11]. Saponins in the leaves of papaya also have potential as larvicides. Insects that consume saponins can reduce the activity of the enzyme digestion and absorption of food.

\section{CONCLUSION}

Methanol extract of Carica papaya leaf contain chemical compound s such as flavonoids, terpenoids, saponins and

\begin{tabular}{lll} 
alkaloids which & made & this extract to be potential as \\
\hline \hline 7u 8 uuTreatment & Mortality $(\%)$ & $\mathrm{Lc}_{50}$ \\
\hline $1 \%$ & 93 & \\
$0.75 \%$ & 70 & \\
$0.5 \%$ & 72 & \\
$0.25 \%$ & 55 & \\
Abate $1 \%$ & 100 & \\
Distilled water & 0 & \\
\hline \hline
\end{tabular}

biolarvacide. LC 50 value in concentration $0,225 \%$..

\section{ACKNOWLEDGMENT}

Authors Express Gratitude and Appreciation to the Laboratory of Entomology, Faculty of Biology and Faculty of Pharmacy Universitas Gadjah Mada, Yogyakarta, Indonesia First Page.

\section{REFERENCES}

[1] A. Kardinan, "Tanaman Pengusir dan Pembasmi Nyamuk".Jakarta: Agro Media Pustaka,2003

[2] Natadisastra,"Parasitologi Kedokteran”.Jakarta:Penerbit Buku Kedokteran EGC,2005

[3] B.Chandra."Pengantar Kesehatan Lingkungan".Jakarta: Penerbit Buku Kedokteran, 2007

[4] A. Heru."Kader Kesehatan Masyarakat".Jakarta: Penerbit Buku Kesehaatan, 1993

[5] A.P.Rumengan." Uji Larvasida Nyamuk (Aedes Aegypti) dari Ascidian (Didemnum Molle), 'Jurnal Perikanan dan Kelautan, vol 6, pp. 2, 2010

[6] H,Sesanti.,A.A.Arsunan, and I. Hasanuddin, "Potential Test of Papaya Leaf and Seed Extract (Carica Papaya) as Larvacide against Anopheles Mosquito Larvae Mortality",International Journal of Scientific and Research Publications,vol 4, pp.1-7,June 2014

[7] Seigler DS, Pauli GF, Nahrstedt A, Leen R ," Cyanogenic allosides and glucosides from Passiflora edulis and Carica papaya", Phytochemistry 60:873-882,2002 https://doi.org/10.1016/S0031-9422(02)00170-X

[8] Shadana, "Efek Larvasida ekstrak ethanol daun papaya (Carica Papaya L.) terhadap larva Aedes aegypti," Universitas Riau, 2014

[9] WHO,"Manual Book of World Health Organization,"'Re-arranging by:Rr.Upiek Ngesti W. Astuti.Parasitology Laboratory,Faculty of Biology UGM,1981

[10] Harbone,J.B, “Metode Fitokimia,"translated by Padma,W.K and Sudiro,Institut Teknologi Bandung,Bandung

[11] Rustaman.M, Abdulrahman.J.A,Anshori,’'Skrining Fitokimia Tumbuhan di Kawasan Gunung Kuda Kabupaten Bandung sebagai penelaah Keanekaragaman Hayati," Laporan Penelitian,Fakultas matematika dan Ilmu Pengetahuan Alam,Universitas Padjajaran,2006

[12] Abbott WS. A method of computing the effectiveness of an insecticide. Journal of Economic Entomology, 18:265-267,1925 https://doi.org/10.1093/jee/18.2.265a

[13] Pancharoen C, Kulwichit W, Tantwichien T, Thisyakorn U, Thisyakorin C, Dengue infection: global concern. J Med Assoc Thai, 85:25-33, 2002

[14] Konvendan,K., K.Murugan, A.N.Kumar, S.Vincent,J.SHwang, "Bioefficay of Larvicdial and pupicidal propertiesof Carica papaya (Caricaceae) leaf extract and bacterial insecticide,spinosad, against chikungunya vector Aedes aegypti (Diptera: Culicidae)",Parasitol Res 110:669-678,2012 https://doi.org/10.1007/s00436-011-2540-z 
[15] Janatunaim,R.Z,N.E.Margiyanti,R.V,Agustin,I.Fathoni,D.Willianto, RC.H.Soesilohadi,."Ethanolic extract of sidewalk food stall's cucumber (Cucumis sativus) waste as an inhibitor for Aedes aegypti's egg hatchability in laboratory scale",International Journal of Advances in Science and Technology (IJAST),pp:236-240,2014. 